\title{
The role of diagnostic hysteroscopy in abnormal uterine bleeding and its histopathological correlation following blind dilatation and curettage
}

\author{
Hariharan Valson, Chinmay Kulkarni*, Sukanya Mukerjee, Shylaja N. Gowda
}

Department of Obstetrics and Gynaecology, DM Wayanad Institute of Medical Sciences, Wayanad, Kerala, India

\author{
Received: 01 February 2016 \\ Accepted: 10 February 2016 \\ *Correspondence: \\ Dr. Chinmay Kulkarni, \\ E-mail: kulkarnichinnu@gmail.com
}

Copyright: () the author(s), publisher and licensee Medip Academy. This is an open-access article distributed under the terms of the Creative Commons Attribution Non-Commercial License, which permits unrestricted non-commercial use, distribution, and reproduction in any medium, provided the original work is properly cited.

\begin{abstract}
Background: Abnormal uterine bleeding (AUB) is a common gynecological disorder in women. To render appropriate treatment it is vital to establish the correct diagnosis, in this backdrop we have studied the utility of hysteroscopy as a diagnostic procedure against a blind dilatation and curettage. The objectives of the study were hysteroscopic evaluation of abnormal uterine bleeding in reproductive and post-menopausal women. Hysteroscopic findings were compared with the histopathological reports following blind dilatation and curettage.

Methods: It is a prospective study on women with symptoms of AUB for a period of one year from Oct 2014 to Nov 2015. Detailed history and clinical examination with an ultrasound (USG) of pelvis to see for endometrial thickness and any structural abnormality was done. 50 cases were included for hysteroscopy. Endometrial biopsy was taken by blind dilation and curettage (D \& C) and sent for histopathological examination (HPE). The hysteroscopic and histopathological findings were analyzed.

Results: Both hysteroscopy and (D \& C) were accurate when an abnormality was diagnosed, giving a specificity of $96.4 \%$ and $96.4 \%$ respectively and positive predictive value of $(95.2 \%$ versus $94.4 \%)$. The ability to diagnose a lesion was more with hysteroscopy i.e. sensitivity in comparison to curettage, (90.9\% versus $77.4 \%$ ), while a negative diagnosis was less wrongly made with hysteroscopy in comparison to curettage (false negative rate: $9.1 \%$ versus $22.7 \%$ ). In intracavitary lesions like polyp, hysteroscopy gave $100 \%$ accuracy.

Conclusions: Hysteroscopy is a sensitive diagnostic procedure that provides useful information in all intracavitary lesions and has a higher sensitivity and specificity. A blind D \& C for AUB may miss focal lesions including endometrial carcinoma, hence hysteroscopy is advisable.
\end{abstract}

Keywords: Abnormal uterine bleeding, Hysteroscopy, Endometrial carcinoma, Dilatation and curettage

\section{INTRODUCTION}

AUB is one of the commonest conditions for which patients come to the gynecological out-patient. Any deviation from the normal pattern of menstrual bleeding is called as abnormal uterine bleeding. AUB is responsible for more than one-third of gynecologic consultations and nearly two-thirds of hysterectomies. ${ }^{1,2}$ It is estimated that a woman has a 1 in 20 lifetime chance of consulting her gynaecologist because of heavy menstrual bleeding. ${ }^{3}$ Inconsistencies in nomenclature and lack of standardized methods of classification have hampered investigation and management of AUB. In an effort to bring improvement, Federation of International Gynecology and Obstetrics (FIGO) have approved a classification system for abnormal uterine bleeding. It classifies the causes into two categories structural and functional. It is described by the acronym PALM COEIN. $^{4}$ 
PALM (structural): P- Polyp, A-Adenomyosis, LLeiomyoma, M-Malignancy.

COEIN (functional)): C-Coagulopathies, O-Ovulatory dysfunction, E-Endometrial, I-Iatrogenic, N-Not yet classified.

Diagnostic D \& C was an important diagnostic procedure for the diagnosis of AUB for many years and advent of hysteroscopy has led to a new era in the diagnosis of AUB. Diagnostic D \& C is a blind procedure and likely to miss many diagnosis. Hysteroscopy involves direct visualization of the uterine cavity and biopsy can be taken under direct visualization. "A vigilant eye in the uterine cavity is better than numerous blind curettages" Lindmann. Hence it is now considered as gold standard for diagnosis of AUB. ${ }^{5}$

\section{METHODS}

This study was carried out over a period of 1 year. Women of reproductive age group, above 20 years, perimenopausal and post-menopausal women were included in the study. The patients with adnexal masses, and cervical lesions, bleeding diathesis were excluded from the study. 50 cases of AUB were included in the study. These patients were seen in the outpatient department, a detailed menstrual history, both systemic and gynecological examination was done. USG pelvis was done to detect any structural abnormality and to see the endometrial thickness. Patients were admitted on D7D10 of their menstrual cycle. In case of post-menopausal woman, they were prepared and admitted when the bleeding decreased or stopped. Hysteroscopy was performed with $4 \mathrm{~mm}$ rigid scope with normal saline as distending medium under general anesthesia. The endometrium was described as normal, atrophic, hyperplastic based on the typical appearance of the endometrium. All the intracavitary lesions like endometrial polyps, sub mucous myoma were seen and documented. Under the same sitting, a blind curettage was done and the endometrium sent for HPE. Statistical results: McNemar's chi-squared $=1.5$, d.f $=1, \mathrm{p}$-value $=$ 0.220 .

\section{RESULTS}

Age group of the patients ranged from 30-64 years and the higher prevalence of AUB was seen in the age group 41 to 50years (Table 1). Mean age was 45 years. Menorrhagia 44\% (22) was the most typical presentation (Table 2).

Abnormal findings were seen in 21 patients (42\%), while the remaining 29 patients $(58 \%)$ showed normal endometrium (Table 3).

Amongst the 18 cases which were reported to be abnormal, 6 patients (12\%) had hyperplastic (Figure 1) endometrium (4 simple hyperplasia without atypia, 2 simple hyperplasia with atypia), 4 patients $(8 \%)$ had polyp (Figure 2), 4 (8\%) patients had atrophic endometrium (Figure 3), 2 had endometritis (Table 4). Histopathology findings corroborate the hysteroscopically detected cases of hyperplasia, atrophic endometrium and endometritis.

Table 1: Age distribution of AUB patients.

\begin{tabular}{|llll|}
\hline Age in years & Normal & Abnormal & Percentage \\
\hline $20-30$ & Nil & Nil & $0(0 \%)$ \\
\hline $31-40$ & $3(6 \%)$ & $2(4 \%)$ & $5(10 \%)$ \\
\hline $41-50$ & $22(44 \%)$ & $8(16 \%)$ & $30(60 \%)$ \\
\hline$>51$ & $4(8 \%)$ & $11(22 \%)$ & $15(30 \%)$ \\
\hline Total & $29(58 \%)$ & $21(42 \%)$ & $50(100 \%)$ \\
\hline
\end{tabular}

Table 2: Distribution of patients according to menstrual abnormality in AUB $(n=50)$.

\begin{tabular}{|lll|}
\hline Type & $\begin{array}{l}\text { Number of } \\
\text { patients }\end{array}$ & Percentage (\%) \\
\hline Menorrhagia & 22 & 44 \\
\hline Polymenorrhea & 13 & 26 \\
\hline $\begin{array}{l}\text { Postmenopausal } \\
\text { bleeding }\end{array}$ & 7 & 14 \\
\hline Metrorrhagia & 5 & 10 \\
\hline Oligomenorrhea & 3 & 6 \\
\hline
\end{tabular}

Table 3: Distribution of patients according to hysteroscopic findings.

\begin{tabular}{|lll|}
\hline Findings & No. of patients (n) & Percentage (\%) \\
\hline Normal & 29 & 58.0 \\
\hline Hyperplastic & 6 & 12.0 \\
\hline Atrophic & 4 & 8.0 \\
\hline Polyp & 8 & 16.0 \\
\hline $\begin{array}{l}\text { Submucous } \\
\text { myoma }\end{array}$ & 2 & 4.0 \\
\hline $\begin{array}{l}\text { Endometrial } \\
\text { carcinoma }\end{array}$ & 1 & 2.0 \\
\hline Total & 50 & 100 \\
\hline
\end{tabular}

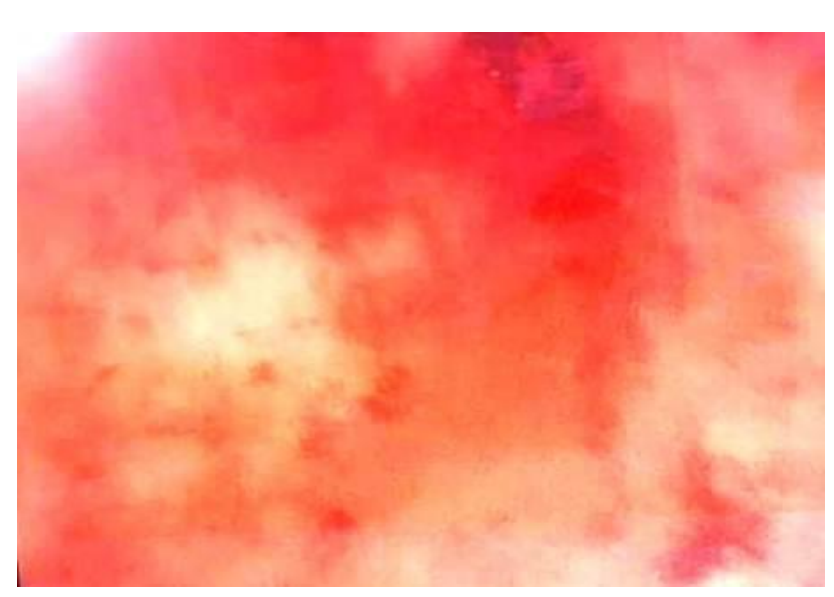

Figure 1: Hyperplastic endometrium. 


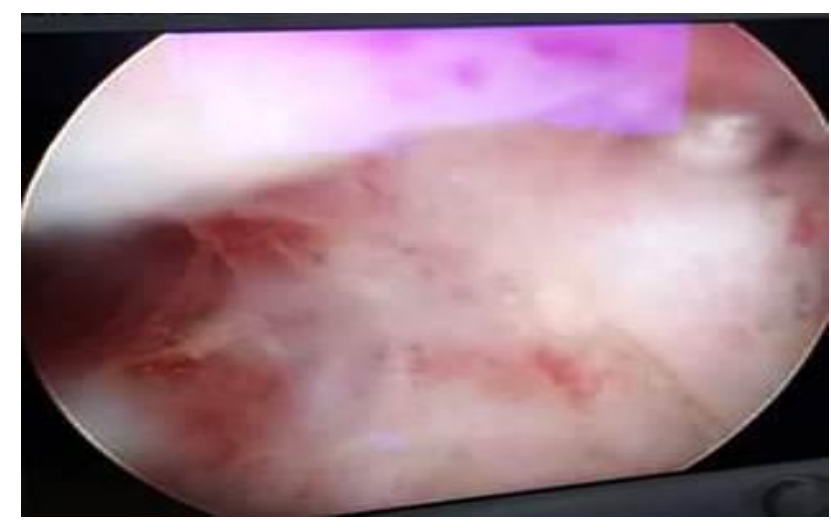

Figure 2: Atrophic endometrium.

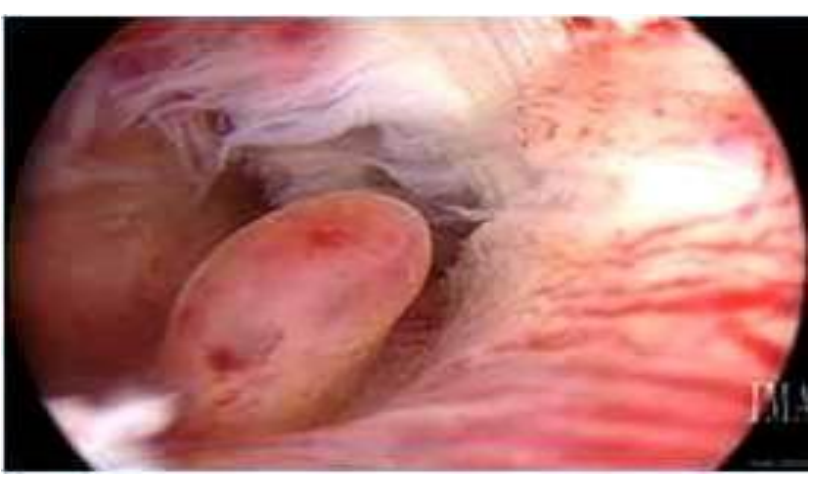

Figure 3: Endometrial polyp.
Table 4: The histopathological findings $(n=50)$.

\begin{tabular}{|lll|}
\hline Findings & $\begin{array}{l}\text { No of } \\
\text { patients (n) }\end{array}$ & $\begin{array}{l}\text { Percentage } \\
(\%)\end{array}$ \\
\hline Normal & 32 & 64.0 \\
\hline $\begin{array}{l}\text { Simple hyperplasia } \\
\text { without atypia }\end{array}$ & 4 & 8.0 \\
\hline $\begin{array}{l}\text { Simple hyperplasia } \\
\text { with atypia }\end{array}$ & 2 & 4.0 \\
\hline $\begin{array}{l}\text { Atrophic } \\
\text { endometrium }\end{array}$ & 4 & 8.0 \\
\hline $\begin{array}{l}\text { Myoma } \\
\text { (submucous) }\end{array}$ & 1 & 2.0 \\
\hline Polyp & 4 & 8.0 \\
\hline Endometritis & 2 & 4.0 \\
\hline $\begin{array}{l}\text { Endometrial } \\
\text { carcinoma }\end{array}$ & 1 & 2.0 \\
\hline Total & 50 & 100 \\
\hline
\end{tabular}

Of the 50 patients who underwent hysteroscopy and curettage, 42 patients (84\%) had the same tissue diagnosis in both hysteroscopy and curettage. Hysteroscopy revealed more information than curettage in $5(10 \%)$ cases and curettage revealed more information in $2(4 \%)$ cases. Out of the 32 cases said to be normal in HPE study, 4 cases of polyp and 1 case of submucous myoma was missed by D \&C (Table 5).

Table 5: Showing clinicopathological correlation.

\begin{tabular}{|lllllllll|}
\hline $\begin{array}{l}\text { Hysteroscopic } \\
\text { findings }\end{array}$ & \multicolumn{1}{l}{ Histopathological findings } & & & \\
\hline No of cases & & Normal & $\begin{array}{l}\text { Endomet- } \\
\text { rial polyp }\end{array}$ & $\begin{array}{l}\text { Hyper- } \\
\text { plasia }\end{array}$ & $\begin{array}{l}\text { Submuc- } \\
\text { ous fibroid }\end{array}$ & $\begin{array}{l}\text { Endomet- } \\
\text { rial atrophy }\end{array}$ & $\begin{array}{l}\text { Endomet- } \\
\text { rial CA }\end{array}$ & $\begin{array}{l}\text { Endomet- } \\
\text { ritis }\end{array}$ \\
\hline Normal & 29 & 32 & 0 & 0 & 0 & 0 & 0 & 0 \\
\hline $\begin{array}{l}\text { Endometrial } \\
\text { polyp }\end{array}$ & 08 & 0 & 04 & 0 & 0 & 0 & 0 & 0 \\
\hline Hyperplasia & 06 & 0 & 0 & 06 & 0 & 0 & 0 & 0 \\
\hline $\begin{array}{l}\text { Sub mucous } \\
\text { fibroid }\end{array}$ & 02 & 0 & 0 & 0 & 01 & 0 & 0 & 0 \\
\hline $\begin{array}{l}\text { Endometrial } \\
\text { atrophy }\end{array}$ & 04 & 0 & 0 & 0 & 0 & 04 & 0 & 0 \\
\hline $\begin{array}{l}\text { Endometrial } \\
\text { CA }\end{array}$ & 01 & 0 & 0 & 0 & 0 & 0 & 01 & 0 \\
\hline $\begin{array}{l}\text { Endomet- } \\
\text { ritis }\end{array}$ & 0 & 0 & 0 & 0 & 0 & 0 & 0 & 02 \\
\hline
\end{tabular}

Both hysteroscopy and curettage were accurate when an abnormality was diagnosed, giving a specificity of $96.4 \%$ and $96.4 \%$ respectively and positive predictive value of $95.2 \%$ and $94.4 \%$ respectively (Table 6 ). The ability to diagnose a lesion was more with hysteroscopy i.e. sensitivity in comparison to curettage, $(90.9 \%$ versus
$77.4 \%$ ) while a negative diagnosis was less wrongly made with hysteroscopy in comparison to diagnostic curettage (False negative rate: $9.1 \%$ versus $22.7 \%$ ). 
Table 6: Comparison of the validities.

\begin{tabular}{|lll|}
\hline & Hysteroscopy & Histopathology \\
\hline Sensitivity & $90.9 \%$ & $77.3 \%$ \\
\hline Specificity & $96.4 \%$ & $96.4 \%$ \\
\hline PPV & $95.2 \%$ & $94.4 \%$ \\
\hline NPV & $93.1 \%$ & $84.4 \%$ \\
\hline Accuracy & $94 \%$ & $88 \%$ \\
\hline
\end{tabular}

\section{DISCUSSION}

Abnormal uterine bleeding is one of the most frequently encountered conditions in gynecology, as quoted by Prentice A. ${ }^{6}$ Till recently the usual method of evaluating abnormal uterine bleeding was dilatation and curettage. The diagnosis was obtained by this manner in most patients, yet in about $10 \%$ blind curettage; may miss the focal lesions. Hysteroscope offers a valuable tool in the hands of the gynecologist. Hysteroscopic inspection of uterine cavity is a simple and well accepted method. The direct real time visualization, real-color, hydrated, wellilluminated, and augmented vision of the uterine cavity make this diagnostic tool very accurate to detect minute focal endometrial pathology and small lesions and helping us to take well guided direct biopsies. Hysteroscopic examination predicts endometrial lesions with a good accuracy as well as endometrial aspect characterization, adopting a nomenclature similar to that used by the pathologist. This approach makes correlation between hysteroscopic findings and histopathological results easier. ${ }^{7}$ The use of hysteroscopy in abnormal uterine bleeding is replacing the blind curettage, as it "sees" and "decides" the cause. This is because the uterine cavity can be observed panoramically and the area in question can be curetted for histopathological examination. In fact, it is the eye in the uterus. ${ }^{8,9}$ The complication rate of the procedure is very less; hence nowadays many gynecologists are performing office hysteroscopy. ${ }^{10}$ In our study there were no operative complications. In the large study done by Singhi et al, the complication rate was $0.6 \% .^{11}$ The complications in comparison to $\mathrm{D} \& \mathrm{C}$ are much lower, as hysteroscope is inserted under vision. ${ }^{12}$ The most common finding was endometrial polyp (16\%). The majority of other studies also state the highest incidence of endometrial polyp (32.5\% Raquel et al, 37.6\% Cordeiro et al). ${ }^{13,14}$ The type of abnormal hysteroscopic findings vary according to the age group and presentation. In our series of patients, endometrial polyp and hyperplasia were the predominant findings with symptoms of menorrhagia and metrorrhagia (18\%). Our results are comparable to results published by other authors (Table 7).

The abnormal findings on hysteroscopy ranged from $50 \%$ to $74 \%$ in other studies. Our study showed abnormality in $42 \%$ of the patients. Of the 21 cases with abnormal findings on hysteroscopy (Table 8), commonest was endometrial polyp (16\%), followed hyperplasia (12\%), and submucous myoma (4\%).
Table 7: Comparative study with other authors.

\begin{tabular}{|lllll|}
\hline S.no & Author (year) & $\begin{array}{l}\text { No of } \\
\text { cases }\end{array}$ & Normal & Abnormal \\
\hline 1 & Sheetal Patil $^{15}$ & 100 & $50 \%$ & $50 \%$ \\
\hline 2 & Dasgupta $^{16}$ & 252 & $38.8 \%$ & $61.2 \%$ \\
\hline 3 & Trajkovic $^{17}$ & 239 & $41.02 \%$ & $58.98 \%$ \\
\hline 4 & Aisha Razzaq $^{18}$ & 80 & $37.5 \%$ & $62.5 \%$ \\
\hline 5 & GuinGeeta $^{19}$ & 100 & $26 \%$ & $74 \%$ \\
\hline 6 & $\begin{array}{l}\text { Sudhanshu } \\
\text { Sekhar }^{20}\end{array}$ & 100 & $38 \%$ & $62 \%$ \\
\hline 7 & Singh S et al $^{21}$ & 100 & $48 \%$ & $52 \%$ \\
\hline 8 & Present study $^{2}$ & 50 & $58 \%$ & $42 \%$ \\
\hline
\end{tabular}

Table 8: Commonest endometrial pathology (comparison with other authors).

\begin{tabular}{|lllll|}
\hline S.no & Author(year) $^{15}$ & Polyp & Hyperplasia & Myoma \\
\hline 1 & Sheetal Patil $^{15}$ & $9 \%$ & $18 \%$ & $11 \%$ \\
\hline 2 & Dasgupta $^{16}$ & $12.3 \%$ & $25.7 \%$ & $18.2 \%$ \\
\hline 3 & Trajkovic $^{17}$ & $20.5 \%$ & $8.5 \%$ & $7.7 \%$ \\
\hline 4 & $\begin{array}{l}\text { Aisha } \\
\text { Razzaq }^{18}\end{array}$ & $18.8 \%$ & $17 \%$ & $11.3 \%$ \\
\hline 5 & GuinGeeta $^{19}$ & $28 \%$ & $30 \%$ & $16 \%$ \\
\hline 6 & $\begin{array}{l}\text { Sudhanshu } \\
\text { Sekhar }^{20}\end{array}$ & $18 \%$ & $16 \%$ & $10 \%$ \\
\hline 7 & Singh S et al & \\
\hline 8 & Present study & $16 \%$ & $26 \%$ & $07 \%$ \\
\hline & & $12 \%$ & $04 \%$ \\
\hline
\end{tabular}

The results of our study indicate a high sensitivity and specificity of hysteroscopy in detection of intrauterine pathology $(90.9 \%, 96.4 \%)$. Two cases which were diagnosed as normal by hysteroscopy, turned out to be endometritis by histopathology. The study of Allameh et al; confirmed a sensitivity of $100 \%$ and specificity of $80.5 \%$ and the study of Tandulwadkar et al. $97 \%$ and $98 \%$, respectively. ${ }^{2,23}$ Pasqualotto et al reported sensitivity of hysteroscopy for detection of endometrial polyp as $99 \%$, while Epstein et al reported it as $80 \% .^{24,25}$ In the study of Jakab et al, the sensitivity of hysteroscopy in detection of circumscribed intrauterine lesions was $100 \% .^{26}$ Kelekci et al found sensitivity of $87.5 \%$ and specificity of $100 \%$ for hysteroscopy in detecting intracavitary abnormalities. ${ }^{27}$ In our present study detection of intracavitary lesion was $100 \%$. Hysteroscopy diagnosed polyps, hyperplasia and sub mucosal myoma with $100 \%$ accuracy. The confirmation of the diagnosis was made in post hysterectomy specimens sent for histopathology, thereby yielding sensitivity, specificity, PPV, NPV of $100 \%$. Patil et al and Panda et al, also reported accuracy of $100 \%$ in the diagnosis of endometrial polyp and submucous myoma. ${ }^{15,28}$ This was comparable to other study. Whereas Velle et al obtained diagnostic accuracy of $88.6 \%$ In case of endometrial hyperplasia Loverro et al stated the sensitivity, specificity, PPV, NPV of 98,95,63,99\% respectively. ${ }^{7,29}$ Arslan et al reported a PPV of $71.4 \%$ and NPV of $95.4 \%$ in diagnosis of endometrial hyperplasia. In one of the 
latest study done by Chaudhari KR, Sathe P, the sensitivity, specificity, Positive Predictive Value (PPV), Negative Predictive Value (NPV) and accuracy of diagnostic hysteroscopy in the study was $98.3 \%, 80.5 \%$, $89.7 \%, 96.7 \%$ and $91.8 \%$ respectively. ${ }^{30}$ In our study, the diagnostic hysteroscopy had sensitivity of $90.9 \%$ specificity of $96.4 \%$, PPV of $95.2 \%$ and NPV of $93.1 \%$, and accuracy of $94 \%$. Hysteroscopy diagnosed 4 cases of atrophic endometrium; Histopathological examination confirmed the findings, giving the accuracy of $100 \%$. The incidence of endometrial cancer that is seen in the literature is generally higher. ${ }^{31}$ Abnormal peri and postmenopausal bleeding is associated with endometrial cancer in about $10 \%$ of cases. ${ }^{32}$ The lower incidence in our study was may be due to the patients with postmenopausal bleeding were taken up for fractional curettage, which is still opted by many of the gynecologists in our setup.

The accuracy of hysteroscopy in this study is $94 \%$ and that of histopathology was $88 \%$. In the present study, the results of hysteroscopy and diagnostic curettage were in agreement in $84 \%$ of patients, hysteroscopy revealed more details in $12 \%$ of cases, which was not detected in diagnostic curettage while in $4 \%$ of the cases diagnostic curettage gave a diagnosis of endometritis which were seen as normal in hysteroscopy.

\section{CONCLUSIONS}

Hysteroscopy is emerging as the new gold standard for the evaluation of abnormal uterine bleeding. The diagnostic accuracy of hysteroscopy is very high compared to D \& C in intracavitary lesions D \& C can miss focal lesions which can be picked up by hysteroscopy. Endometrial biopsy under hysteroscopic guidance can play a supporting role in supplementing the diagnostic accuracy of hysteroscopy. Adequate diagnosis is crucial for the selection of relevant treatment of abnormal uterine bleeding and avoidance of unnecessary major surgical procedure.

\section{Funding: No funding sources}

Conflict of interest: None declared

Ethical approval: The study was approved by the Institutional Ethics Committee

\section{REFERENCES}

1. Lasmar RB, Dias R, Barrozo PR, Oliveira MA, Coutinho Eda S, da Rosa DB. Prevalence of hysteroscopic findings and histologic diagnoses in patients with abnormal uterine bleeding. Fertil Steril. 2008;89(6):1803-7.

2. Gimpelson RJ, Rappold HO. A comparative study between panoramic hysteroscopy with directed biopsies and dilatation and curettage. A review of 276 cases. Am J Obstet Gynecol. 1988;158:489-92.

3. Schorge JO, Schaffer JI, Halvorson LM et al. 2nd ed. New York. Mc Graw Hill. 2008.
4. Munro MG, Critchley HOD, Broder MS, Fraser IS. FIGO classification system (PALM-COEIN) for causes of abnormal uterine bleeding in nongravid women of reproductive age. International Journal of Gynecology and Obstetrics. 2011;113:3-13.

5. Bradley H, Nezhat F. Hysteroscopy. In: Nezhat C. Nezhat's operative gynecologic laparoscopy and hysteroscopy. New York: Cambridge University press. 2008;577-9.

6. Prentice A. When does heavy flow merit treatment? Practitioner. 2000;244:179-82.

7. Elbareg AM, Elmahashi MO, Essadi FM. Evaluation of Intrauterine Pathology: Efficacy of hysteroscopy in comparison to Histopathological Examination. Reproductive System \& Sexual Disorders: Current Research. 2015;4:149.

8. Velle RF. Hysteroscopic evaluation of patients with abnormal uterine bleeding. Surg Gynecol Obstet. 1981;153(4):521-6.

9. Baggish M, Guedj H, Valle R. Hysteroscopy: Visual perspectives of uterine anatomy, physiology and pathology. 3rd ed. London: Lippincott Williams \& Wilkins. 2007:330-59.

10. Nikolaou D, Salman G, Richardson R. Operative hysteroscopy in the outpatient setting: its role within a gynaecology service. Gynaecol Surg. 2009;6(1):214.

11. Singhi A. Comparison of complications rates in endoscopic surgery performed by a clinical assistent vs. An experienced endoscopic surgeon. J Gynecol Endosc Surg. 2009;1(1):40-6.

12. Baggish M, Guedj H, Valle R. Hysteroscopy: Visual perspectives of uterine anatomy, physiology and pathology,3rd edition. London: Lippincott Williams \& Wilkins. 2007:15-30.

13. Raquel P, Claudio G, Suzana A, Alice V. Tamoxifen use and endometrial lesions: hysteroscopic, histological and immunohistohemical findings in postmenopausal women. Menopause. 2009;16(2):293-300.

14. Cordeiro A, Condeco R, Sousa F, Leitno C. Office hysteroscopy after ultrasonographic diagnosis of thickened endometrium in postmenopausal women. Gynecol Surg. 2009;(4):317-22.

15. Patil SG, Bhute SB, Inamdar SA, Neema SA, Deepti SS. Role of diagnostic hysteroscopy in abnormal uterine bleeding and its histopathological correlation. J Gynecol Endosc Surg. 2009;1(2):98-104.

16. Subhankar D, Barunoday C, Rejual K. Abnormal uterine bleeding in perimenopausal age: Diagnostic options and accuracy. The journal of obs and gyn of India. 2011;189-94.

17. TrajkovicDinic SP, Kopitovic V, Antic V. Role of hysteroscopy in evaluation of patients with Abnormal uterine bleeding. Scientific Journal of the faculty of medicine in Nis. 2011;28(3):177-81.

18. Razzaq A, Shukar-ud-Din S, Soomro N. Role of diagnostic hysteroscopy in case of abnormal uterine bleeding. Pak J Surg. 2011;27(4):309-15. 
19. Gita G, Kaur SS, Arvind L, Shashi K. Hysteroscopy in evaluation of abnormal uterine bleeding. The journal of obs and gyn of India. 2011;61(5):546-9.

20. Nanda SS, Dash S, Behera A. Diagnostic value of hysteroscopy in perimenopausal abnormal uterine bleeding compared to histopathologic study of blind $\mathrm{D}$ and $\mathrm{C}$. $\mathrm{J}$ of evolution of medical and dental sciences. 2013;39:74-97.

21. Singh S, Taneja BK, Singh P, Ahlawat R. Role of diagnostic hysteroscopy in abnormal uterine bleeding. Int $\mathbf{J}$ Reprod Contracept Obstet Gynecol. 2014;3(3):544-51.

22. Allameh T, Mohammadiazadeh F. Diagnostic value of hysteroscopy in abnormal uterine bleeding compared to pathology reports. Iran J Reprod Med. 2007;5(2):61-4.

23. Tandulwadkar S, Deshmukh P, Lodha P, Agarwal B. Hysteroscopy in postmenopausal bleeding. J Gynaecol Endosc Surg. 2009;1(2):89-93.

24. Pasqualotto EB, Margossian H, Price LL, Bradley LD. Accuracy of preoperative diagnostic tools and outcome of hysteroscopic management of menstrual dysfunction. J Am Assoc Gynecol Laparosc. 2000;7:201-9.

25. Epstein E, Ramirez A, Skoog L, Valentin L. Trans vaginal sonography, saline contrast sonohysterography and hysteroscopy for the investigation of women with postmenopausal bleeding and endometrium $>5 \mathrm{~mm}$. Ultrasound Obstect Gynecol. 2001;18:157-62.

26. Jakab AJ, Ovari L, Juhasz B , Birinyi L, Bacsko G, Toth Z. Ultrasound diagnosis of focal intrauterine lesions. Orv Hetil. 2002;143:1739-43.
27. Kelekci S, Kaya E, Alan M, Alan Y, Bilge U, Mollamahmutoglu L. Comparison of transvaginal sonography, saline infusion sonography, and office hysteroscopy in reproductive-aged women with or without abnormal uterine bleeding. Fertil Steril. 2005;84:682-6.

28. Panda A, Parulekar SV, Gupta A. Diagnostic hysteroscopy in abnormal uterine bleeding and its histopathological correlation. Journal of $\mathrm{Obs}$ and Gyn of India. 1999;175:74-6.

29. Loverro G, Bettocchi S, Cormio G, Nicolardi V, Porreca MR, Pansini N. Diagnostic accuracy of hysteroscopy in endometrial hyperplasia. Maturitas. 1996:25:187-91.

30. Chaudhari KR, Sathe P. Role of diagnostic hysteroscopy in evaluation of abnormal uterine bleeding and its histopathological correlation. Int $\mathbf{J}$ Reprod Contracept Obstet Gynecol. 2014;3:666-70.

31. Ribeiro CT, Rosa-E-Silva JC, Silva-de-Sá MF, RosaESilva AC, Poli Neto OB, Candido Dos Reis FJ. Hysteroscopy as a standard procedure for assessing endometrial lesions among postmenopausal women. Sao Paulo Med J. 2007;125(2):338-42.

32. Creasman WT. Endometrial cancer incidence, prognostic factors, diagnosis, and treatment. Semin Oncol. 1997;24(1):S1-140-50.

Cite this article as: Valson $\mathrm{H}$, Kulkarni C, Mukerjee $\mathrm{S}$, Gowda SN. The role of diagnostic hysteroscopy in abnormal uterine bleeding and its histopathological correlation following blind dilatation and curettage. Int J Reprod Contracept Obstet Gynecol 2016;5:60914. 